\title{
Race and ethnicity in the construction of the nation in Spain: the case of the Maragatos
}

\author{
Pablo Alonso-González ${ }^{\mathrm{a}, \mathrm{b}}$ (1) \\ ${ }^{a}$ Department of Archaeology, University of Cambridge, Cambridge, UK; ${ }^{\mathrm{b}}$ Incipit-CSIC, \\ Santiago de Compostela, Spain
}

\begin{abstract}
Nationalism and its counterpart, modernism, are projects that involve the attempt to homogenize and incorporate the masses through the creation of a majority identity that usually leads to the classification of certain deviant groups as 'others'. In Spain, civic and ethnic nationalisms driven by the state have historically drawn on cultural and biological notions of ethnicity and race to construct a representation of the Maragatos as 'cursed peoples', while at the same time homogenizing and incorporating them into the nation in practice. By tracing a genealogy of the origins and evolution of the representations of Maragato otherness created during the Enlightenment era, the Franco dictatorship and the current super-modern period, this paper argues that representations of otherness significantly influence current research agendas and understandings of identity well beyond the disappearance of the actual subjects described as others.
\end{abstract}

KEYWORDS Spain; nation building; internal others; Maragatería; ethnicity; identity

ARTICLE HISTORY Received 4 February 2015; Accepted 4 June 2015

\section{Ethnogenesis and nation building}

Nations are as much historic products as constructions based on the institutionalization of certain notions of the social that ground their legitimacy and authority. These notions become part of the dominant political, ideological and symbolic order, which is both imagined and naturalized - that is, rendered socially real - among a collective of people. Nationalism produces a 'sense of political community that conflates peoplehood, territory, and state' (Alonso 1994, 391). The convergence between culture and state can be defined as congruency - that is, an elite-driven attempt based on modern notions of progress and development to impose sociocultural transformations leading to, or aiming at, cultural uniformity (Conversi 2008). Because nationalism tends to conflate culture with nation, and therefore with ethnicity, 'there is a high correlation between cultural homogenisation 
policies and ethnic discrimination' (Conversi 2013, 441). Indeed, nation building promotes cultural homogenization through the construction of a social imaginary of shared blood, territory and heritage, which requires the construction of 'internal others' that deviate - racially or ethnically - from the majority norm. These others adopt different forms in each nation due to the variations in the modes of political incorporation and of conceiving social heterogeneity within its boundaries.

Investigating the reciprocal relations between processes of nation state formation and the production of internal others requires paying attention to the shifting processes whereby culture is naturalized and nature becomes a cultural attribute of ethnicity. This 'genealogical' approach overcomes Gellner's presentist bias by exploring the ways by which the fantasies of congruency and homogenization have been produced and legitimized (Mandelbaum 2013, 2015-2016). Race and ethnicity provide the binding tissue for the symbolic and material construction of the nation by connecting people, territory and social imaginaries of homogeneity. Nationalism and modernism lead to the creation of cultural representations of different others, and the homogenization and incorporation of alterity - other modes of existence - into the nation state. Through this process, certain others are excluded from the 'real' heritage of the nation through the production of ethnic and racial difference, while at the same time their cultural representations are incorporated into national narratives and images through their study, their use in folklore or commodification.

The traffic between different notions of identity raises the question of their incorporation into nation state building processes and the debate between the civic and ethnic roots of national polities. The literature describes the civic conception of the nation as a community of destiny based on individual citizens sharing territory, legislation, rights and institutions, as exemplified by Republican France. Ethnic and cultural nationalisms highlight the distinctive linguistic, racial, ancestral, cultural, or religious factors that underpin national communities, as exemplified by Germany. In Spain, it has been traditionally argued that two dominant nation state building canons have existed since the nineteenth century (Muro and Quiroga 2005). The 'civic' idea of Spain emerged with liberalism during the Peninsular War against Napoleon (1808-1814), seeing Spain as a Catholic polity united by a constitutional parliament that respected local autonomy. Moderate liberals incorporated important aspects of history and culture as defining traits of Spain and assumed a correspondence between Catholicism and Spain that almost naturalized religious belief as an ethnic marker. The conservative-traditionalist view of Spain is usually described as 'ethnic'. It considered the Peninsular War as a fight against atheists that should restore the Ancien Régime as the authentic Spanish Golden Age, while liberal and non-Catholic ideas and traditions were seen as anti-Spanish. Absolutists and Carlists fiercely countered most 
attempts of state modernization, while liberals failed to put into practice their reformist agendas. Thus, although distinct tendencies existed, Spanish nationalism has evolved dynamically throughout two centuries to incorporate both civic and ethnic elements into the contentious ideal of nation.

This paper carries out a genealogy of one of the mechanisms through which the social imaginary of cultural homogeneity in Spain has been rendered natural and necessary throughout these two centuries, namely the construction of ethnic and racial others. It examines the historical constitution of these categories by deconstructing their underlying positivist orientations and the conditions of their production in different periods through the case of one of the cursed peoples from Spain: the Maragatos. This analysis reveals the changing forms of 'tracing relatedness through common history and culture (usually glossed as "ethnicity") and through common genealogical origins and "blood" (usually associated with "race")' (Wade 2007, 11). The otherization of the Maragatos has moved from a period of religious marginalization and Enlightenment cultural critique, to biological notions of racial science in the early twentieth century, then shifting to folkloric culturalism during the Franco era. Then, the democratic period after the end of dictatorship in 1975 reflects the abandonment of national metanarratives and the threefold incorporation of identities to the market, the commodification of ethnicity and the revival of genetic racism. By analysing the relation between references to nature and blood, culture and soil, it is possible to analyse the dynamic combination of ethnic and cultural notions in the national imaginary as elaborated in the nation-building processes of the nineteenth and twentieth centuries, all of which resulted in the construction of a cultural representation of the Maragatos as internal others in Spain.

\section{From Enlightenment critique to racial science: the creation of the Maragato difference and homogenization of their alterity}

Catholicism was accorded a central role in grounding Spanish identity at least since the sixteenth century, when the Inquisition became the only unitary Spanish institution 'in the absence of administrative integration and the existence of diverse regional cultures' (Rae 2002, 59). For Rae, a proto-national consciousness first arose against those seen as 'aliens' or 'strangers', usually Jews and Moors (Rae 2002, 60). When these groups were expelled from Spain, the action of the Inquisition shifted to those who had converted to Catholicism, the conversos, and even to the Old Christian population in an attempt to buttress Catholic orthodoxy against the threat posed by the Reformation (Rae $2002,69)$. Spain was unique in Europe in the development of what Grosfoguel and Mielants (2006) have described as a technology of power based on 'purity of blood' devised to preserve the privileges of Old Christians against the conversos. Indeed, they consider that the debate between Las Casas and 
Sepúlveda about the human condition of American Aboriginals provided the initial articulation of racism that would linger in the next five centuries. While Las Casas anticipated cultural racism, considering that Aboriginals had a soul but had to be Christianized, Sepúlveda anticipated biological racism by arguing that they had no soul and could therefore be exploited. Thereafter, 'The Christian-centric global religious hierarchy and the Eurocentric global racial/ethnic hierarchy were increasingly entangled and the distinction between practicing a non-Christian religion and being racialized as an inferior human became increasingly erased' (Grosfoguel and Mielants 2006, 4).

During the eighteenth century, many political reforms were implemented following Enlightenment ideas in the attempt to build a modern nation state in Spain. The project of a centralized Spain that would put an end to the historic atomization of the country persisted during the nineteenth century, emphasizing the need for territorial homogenization (Bel i Queralt 2012, 34). Enlightenment intellectuals advocated the construction of a coherent nation state through the incorporation of different peoples into the national culture and economy. The improvement of communication networks, internal markets and the centralized bureaucracy enabled the expansion of education and the use of Spanish throughout the country (Moreno 2001, 48). This process resembled British 'Anglicization' and French 'Gallicization', but Spain differed from these contexts because of the contested nation-building context of the nineteenth century. The literature has traditionally underscored the 'weakness' of the Spanish state based on the various and competing political projects, the failure of linguistic and state unification, and the endurance of local and regional identities, which led to the emergence of peripheral Basque and Catalan nationalisms during the twentieth century. Recent scholarship has challenged this view by highlighting the compatibility between regionalisms and Spanish national identity (Archilés and Carrion 2013).

Nation state building was tightly related to ethnicization and racialization processes that served as dialectic mirrors against which to affirm the dominant identity. This took place in a context of decadence of aristocratic classes and the economic ascent of the bourgeoisie and liberal ideas led to a conflict between competing values concerning issues of blood, honour and trade (Callahan 1972). Certain groups were marked as different on the grounds of differential cultural behaviours and endogamy practices: fundamentally profit-making mentalities and intermarriage strategies. Such practices were associated with the idea of the others, perceived as strangers and aliens: Jews, Moors, or Protestants. Although both liberal and conservative Spanish nationalist projects assumed the idea of racial fusion rather than purity (Goode 2009), the association of 'purity' with 'honour', and 'richness' with 'shame', as well as anti-Semitism, endured among numerous sectors of Spanish society throughout the nineteenth century. Catholicism was almost naturalized as an ethnic component of national unity, which had to be 
achieved through 'the conjunction of legislation and faith' so that 'the different races disappear and the "nation" becomes "one" before the law, the family and the forum' (Lafuente and Pérez Garzón [1850] 2002, 20-21, italics added). The biopolitical emphasis on the abolition of the 'different races' shows how 'ideas about national heritage, culture and history were infused with notions of blood and genealogy' (Wade 2007,6). This led to the collective racialization and ethnicization of certain others, which was 'a requirement, through the dynamics of stereotyping and identity contrast, for helping to set boundaries and mark off the dynamics of the we' (Appadurai 2006, 50). Throughout Europe, those others were usually the Jews (García-Arenal and Rodríguez Mediano 2013), but also other so-called cursed peoples such as the Cagots in France, or, in Spain, the Vaqueiros d'Alzada, Chuetas, Quinquis, Agotes, Pasiegos, Maragatos and above all Gypsies (Michel 1847; Miner Otamendi 1978).

A social group located in north-west Spain, the Maragatos, were first referenced in written records dating to the fifteenth century. They inhabited tiny villages in the region of León but, contrary to the other peasant families with which they cohabited, they combined subsistence agriculture with long-distance mule trade. This activity ensured their accumulation of vast amounts of capital unattainable by their peasant neighbours. As most cursed peoples, they were considered sinful for their profit-making mentalities and great spatial mobility. This explains how the analogies established between the Maragatos and the Jews derive from their occupations rather than from any sort of historic evidence (Freeman 2011). As a conservative and privileged group, the Maragatos preserved their traditions, dress and monumental architecture, which were gradually assumed by their peasant cohabitants. Their power even changed the name of the region they inhabited from Somoza to Maragatería - land of the Maragatos. The development of their own codes of value and honour rendered their social behaviour even more suspicious and reinforced the social perception of their difference, enhanced by their high levels of endogamy and complex intermarriage strategies aimed at the maintenance of wealth within the group (Rubio Pérez 2003) (Figure 1).

The main trade route of the Maragatos connected Galicia with Madrid, where people saw them as different and too odd to be Spanish. Thus, the perception of their difference was not only of official or intellectual origin, but also popular. Inspired by the popular perceptions of the Maragatos, a monk called Sarmiento (1787) described their differential traits. He took for granted their non-Spanish roots and situated their origins among African Berber tribes or Semitic groups, establishing a long-lasting analogy between internal others and non-Catholic peoples - usually Jews and Muslims, or the 'suspicious' conversos. Nationalist and modernist ideals were embodied by Enlightenment intellectual Jovellanos ([1782] 1981), who combined an interest in the homogenization and material progress of Spain 


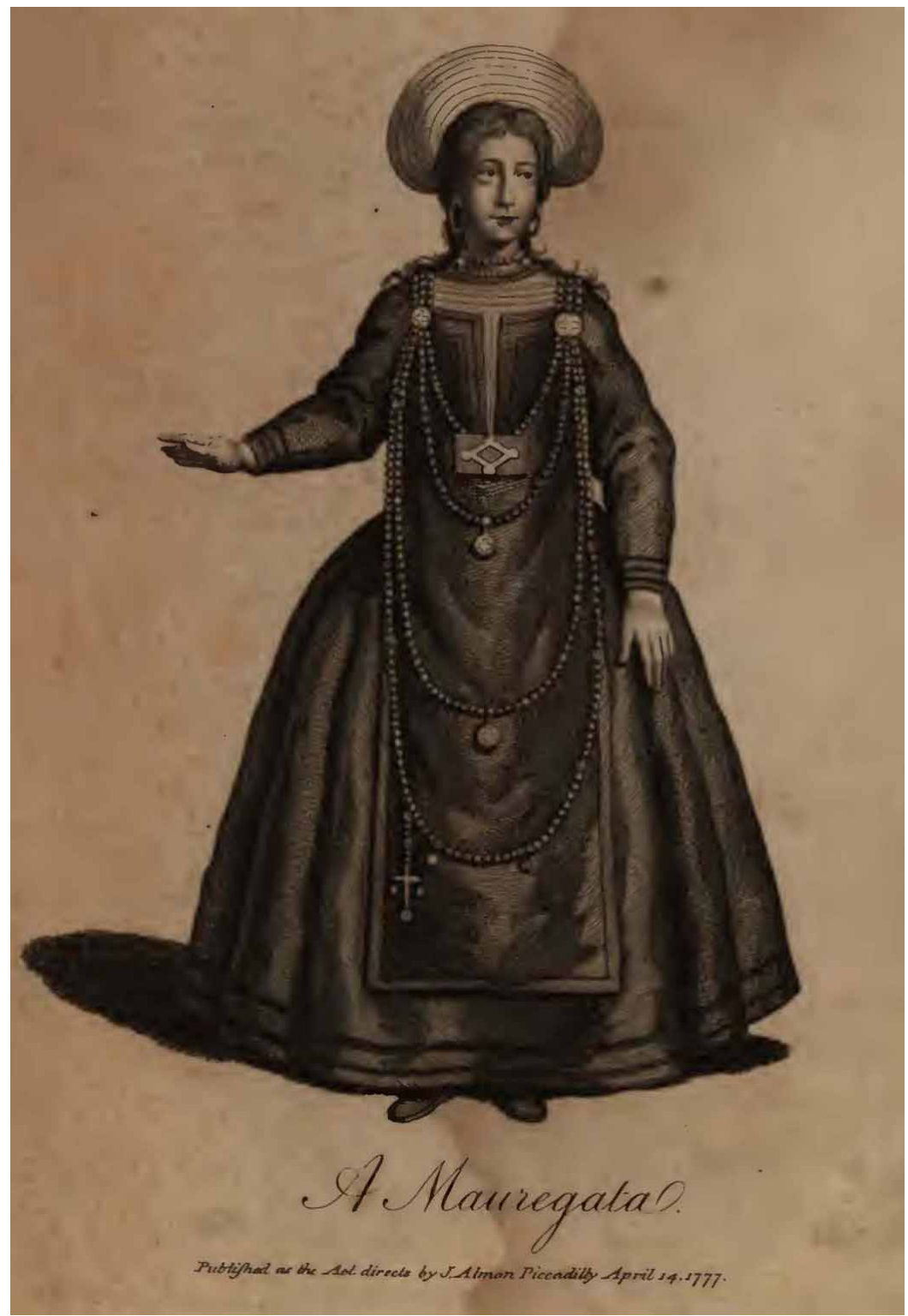

Figure 1. A Maragata depicted by William Dalrymple in 1777.

with an academic account of those groups considered uncivilized. He wondered about the origins of the Maragatos, highlighting their peculiar kinship systems whereby they 'reject the marriages with other villagers and are despised by them' (Jovellanos 1858, 313).

Many European travellers underscored the differential traits of the Maragatos during the eighteenth and nineteenth centuries (Ford 1906; Escudero 
Barbero and García-Prieto 1984; Casado and Carreira Vérez 1985). The mythmaking surrounding the Maragatos would reach South America, where they were considered the ascendants of the Gauchos, a group of internal others in Argentina, Uruguay and Brazil. During the second half of the nineteenth and the first half of the twentieth century, most accounts of the Maragatos were folkloric, focusing on questions of origins, traditional objects and culture in connection with a particular land, far from the universal anthropological concern about humankind. Different intellectuals described the Maragatos as descendants of Moors, Carthaginians, Celts, pre-Roman Aboriginals, Jews, or Germanic peoples - that is, as 'impure' Spanish and Catholics (Dozy 1859; Sáez de Melgar 1881; Oliveira Martins 1894; Alonso Garrote 1909; Ciria y Vincent 1909; Morán Bardón 1925). This might have been related to the large amounts of land and properties bought by the Maragatos during the Desamortizaciones (Ecclesiastical confiscations) in the mid-nineteenth century, which were severely criticized by the Church.

During the Restoration period (1874-1923), there was an emergence of studies and inventories of popular culture that generated folkloric images of certain regionalized identities such as Andalusia or the Mediterranean (Archilés and Carrión 2013). This incipient homogeneous national cultural sphere anticipated the regional folklorism that the Franco regime would promote. The loss of the last Spanish colonies in 1898 triggered the 'regenerationist' discourse among intellectuals and scientists. In parallel to the growing influence of civic liberalism and its close association of notions of blood, citizenship and rights, regenerationism was pervaded by a wave of socio-biological Darwinism, historicism and evolutionism that thrived in Europe during the late nineteenth century. The conception of the nation as an organism undergoing evolutionary progress paved the way for the establishment of racial theories to explain the origins of the internal others. The shift from ethnicity to race involved a naturalization of difference and its scientific study as an objective fact, legitimizing the nation-building process as a scientific and rational project (Ortiz García 1996). The various schools of anthropology emerging after 1870 shared similar views of Spain's racial hybridity and attempted to understand how racial fusion occurred (Goode 2009).

The scientific attempt by anthropologists to shed light on the Spanish process of miscegenation was grounded on pre-existing notions of ethnic difference inherent in popular ideas, sometimes spread by folklorists. Concerning the Maragatos, the dominant theories moved from affirming their Semitic origins to supporting their Berber ascendancy - in relation to a shift from a religious to a racial bias. Aragón y Escacena (1902) conducted a physical anthropology characterization of eighty Maragatos, analysing their physical patterns, including skull and nose dimensions, eye colour and stature. He found the physical and sociological resemblances between Berbers and Maragatos so high as to affirm that they should be considered a similar race. The 
scope of his research was conditioned by previous ideas about the Maragatos and by his supervisor, Manuel Antón, who advocated the existence of a specific Libyan-Iberian race. Consequently, the attempt to provide a scientific explanation of ethnicity resulted in the naturalization of difference in terms of race. Aragon y Escacena's work started a lineage of scientific studies about the Maragatos focusing on blood (Hors 1951), human ecology (Bernis 1975), anthropometrics (Caro Dobón 1986), fingertips and prints (Méndez Diego 1982) and genetics (Larruga et al. 2001). Although the folkloric discourse would always be predominant in terms of number of publications and people engaged in it (García Escudero 1953; Carro y Carro 1955; Caro Baroja 2003), the scientific approach to the Maragato race was highly influential and is still used to affirm the otherness of the group.

Paradoxically, discourses reinforcing the ethnicization and racialization of the Maragatos were paralleled by their gradual cultural homogenization and disappearance as a social group. Similar to Weber's (1976) account of the homogenization of peasant cultures in France, the expansion of the railroad network put an end to Maragato mule trade dedication and geographic isolation after 1860. Between 1870 and 1930, most Maragatos migrated to Madrid, Galicia and Latin America, leaving behind a poor peasant region named after them (Alonso González and Álvarez Domínguez 2013). Maragatería became increasingly similar to other rural areas of Spain, although local peasant communities assumed some folkloric elements characteristic of the Maragato group, such as dress, popular music and their demonym.

\section{The folklorization of the Maragato difference during the Franco regime (1939-1975)}

The Franco regime brought together various nationalist projects and combined them in different ways during each period. However, the regime was consistent in its attempt to reconstruct the symbolic image of the country. The attempt to create a uniform Spanish identity generated a highly specific and politicized folkloric regionalism. The underlying objective of this process of invention of tradition was the establishment of symbolic links between romantic and aestheticized folkloric images of ethnic groups representing authenticity and purity, and a certain soil to which they were attached, as metaphors for the Spanish nation (Viejo-Rose 2011). These folkloric representations presented an ideal image of Spanish rural areas as the backbone of the nation, synonym of stability, tradition and fidelity to Catholicism. In parallel, however, the modernization promoted by the regime shattered and homogenized rural communities, which were considered backward.

Folklore was controlled by Coros y Danzas (Choruses and Dances), a corporatist organization aimed at the transformation of popular culture into reified folkloric performances to be celebrated as authentically Spanish 
(Ortiz García 1999). Folkloric regionalism was fuelled by the Nazi defeat leading to the abandonment of racial discourses that had hitherto prevailed in Spain. However, tropes of biological and cultural difference fed each other. As Porqueres i Gené has argued:

blood and soil, far from being opposed, appear as variants of a single theme, that of the presence of the ancestors in the definition of the nation. Land thus becomes a mediator between those who existed in the past and those who currently live on it. (Porqueres i Gené 2002, 58)

References to notions of natural or biological difference became less publicly acceptable as criteria of ethnonational inclusion, but culture was somewhat naturalized through ideas of history and soil, which explains the emphasis on connecting cultures and territory.

Now, the people living in Maragatería - for the sake of simplicity hereafter called 'Maragatos', although no longer referring to the distinct Maragato social group and just to the people who stayed in Maragatería rather than migrating - became one of the preferred groups for the promotion of folkloric regionalism. Their alleged isolation, traditionalism, Catholic fervour and attachment to the soil were turned into a representation of an authentically autochthonous community embodying the values that the regime sought to promote as examples of Spanishness. The Maragatos had been previously folklorized, performing at the wedding of Alfonso XII in 1877, at Alfonso XIII's visit to León in 1902, in Seville in 1908, and in London in 1914. Now, however, their folkloric repertoire was standardized and they became active participants in the construction of the self-image of the nation.

When in 1939, Franco's victorious troops celebrated the Regional Day of Victory in León, the Maragato folkloric group was the foremost protagonist of the parade, winning the collective and individual awards among other Spanish folkloric groups. Eventually, the Maragatos became the folkloric representatives of the region of León, winning the Coros y Danzas national folkloric contest in 1943 and hosting an important celebration of the regime, the II Day of the Counties of the province of León in 1962. The regime supported their tours and parades around Spain and Latin America. Contrary to earlier periods, many official publications and the folkloric image of the Maragatos represented them as a deeply Catholic group (Figure 2).

Studies of the Maragatos thrived at the time, including comparative studies in archaeological excavations (Luengo Martínez 1990), and historic accounts of their culture, economy and legal framework (Martín Galindo 1956; Peña Sanz 1962). They had a significant presence in books about folklore and agricultural tools (Caro Baroja 1973) and in the photo books setting the folkloric representational standards at the time (Ortiz-Echagüe 1943).

Paradoxically, the period of apogee of Maragato folklorization was paralleled by the abandonment in daily life of the last remnants of Maragato 


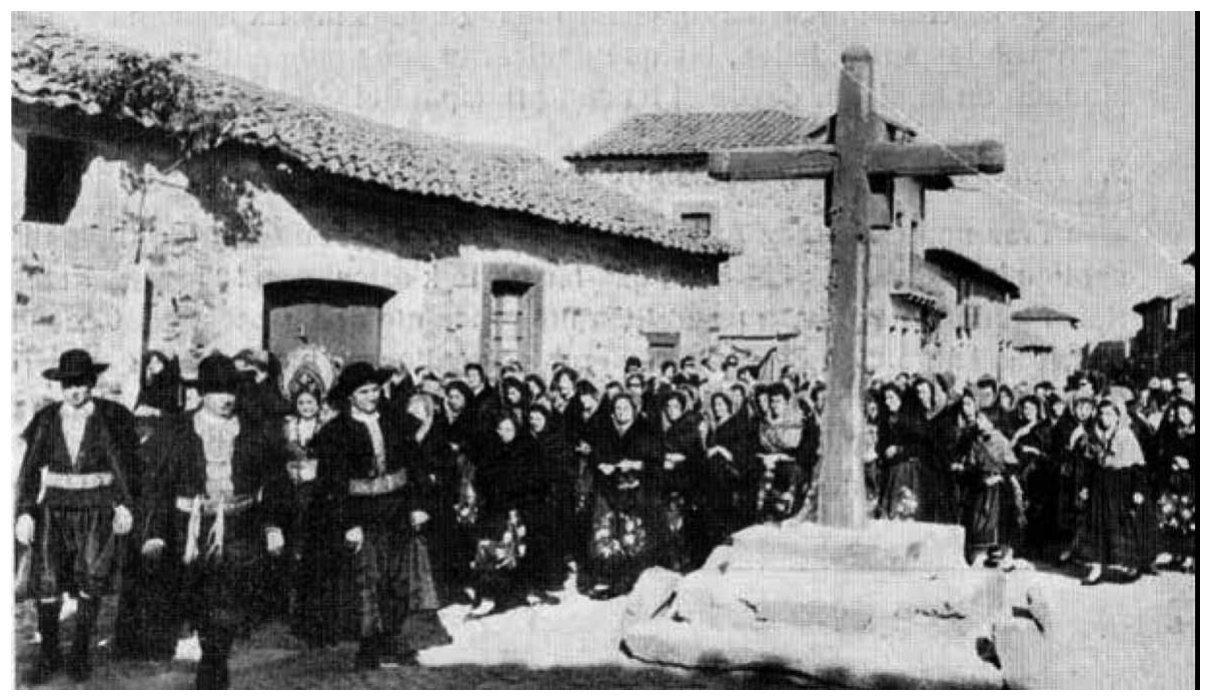

Figure 2. Celebration of the II Day of the Counties of the province of León - in Castrillo de los Polvazares, in 1962. These celebrations were instrumentalized to emphasize the attachment of local communities to the traditional values of the Church, the family and the Spanish nation. II Día Provincial de las Comarcas Leonesas. 1962. Tierras de León, 2 (3): 91-106. 
cultural traits after the 1940s, such as the disappearance of traditional dress. Moreover, although changes in local communities had been continuous during the twentieth century, the process of industrialization after the 1960s saw the culmination of the modernization process imagined centuries ago by Spanish Enlightenment thinkers, provoking a rural exodus that dissolved the traditional ways of life and management of Maragato villages. Thus, while depopulation rates rocketed in Maragatería after 1950, the folkloric image of Maragatos promoted by the regime became widespread in Spain, concealing the process of actual socio-economic disintegration of the area. This shows how the creation of reified images of cultural difference served to further and legitimize the process of social and economic homogenization driven by the nation state.

The emergence of sociocultural anthropology in Spain triggered by the arrival of a wave of foreign researchers reproduced this situation. For Brandes (2011, 33), social anthropology was born in Spain during the Franco period under a significant influence of American - and, I would add, British - anthropology, which unconsciously shared some ideological principles and objects of study with the dictatorship. Indeed, the equation of soil and culture was used to conceal class inequalities and to foster intervillage and interregional conflicts and competition. The turn towards the study of the peasantry led Anglo-American anthropologists to disembark in Spain with some preconceptions about Spanish villages, namely that social identity was largely determined by birthplace, thus fostering the link between culture and territory that the dictatorship was promoting. As Brandes has argued, marginal groups of:

relatively reduced population intimately bounded to specific territories, were among the primary objects of study in Spain. Those groups were socially equivalent at the time with the indigenous groups of the United States: that is, marginal, discriminated, poor, with differential cultural traits from the rest of peninsular cultures. (Brandes 2011, 24)

Even after the demise of the Franco regime in 1975, Spanish social anthropology continued to equate soil with a differential identity. In a sort of neoromanticism, authors sought the autochtonous and uncontaminated cultures that they expected to find in villages. To this end, Maragatería represented a perfect place to carry out research, because, as cultural anthropologist Gutiérrez González $(1983,291)$ underscored in 1983, the folkloric aspects of rural Spain were 'manifested here with a unique idiosyncrasy and traditionalism'. He opened his work on the Maragatos with a citation from Lisón Tolosana, who did his DPhil with Edward Evans-Pritchard in Oxford and who would supervise Ana Melis Maynar's PhD on Maragatería:

As starting hypothesis of anthropological research, it is possible to equate each area or similar way of life with a subcultural area ... a geographic and physical 
environment tends to be associated with an analogous way of life, and this originates a specific subculture. (Lisón Tolosana 1980, 32)

The Maragatos were studied on these premises by Melis Maynar (1976), Martínez Veiga (1981) and Gutiérrez González (1983), engaging in comparisons with other cursed peoples such as the Pasiegos or the Vaqueiros d'Alzada. The underlying idea of an essential connection between soil and culture in these studies was apparent. These changes are related to the shift in Spanish anthropology from carrying out fieldwork in colonial areas to the study of peasants and marginal groups in Spain (Prat Carós 1992, 96). Anthropologists in the richest regions of Spain could conduct fieldwork in underdeveloped areas with 'traditional' communities (Capel Sáez 2009). As Ortiz García $(2003,17)$ has argued, 'the choice of these small and supposedly isolated groups was mediated by a colonial conception of anthropology translated to a closer terrain'.

Sociocultural anthropologists studied what they perceived to be the more authentic representations of Maragato culture, such as their feasts and folkloric performances, thus reifying and neutralizing the political agency of the community under investigation. Indeed, there are no anthropological accounts of the fierce Maragato struggles against the creation of a military firing range in their territory by the Spanish Army in 1982 (Alonso González and Macías Vázquez 2014). The continued ethnicization of the Maragatos was also ensured by the continuation of history-culture approaches to their origins and culture (Quintana Prieto 1978; Alonso Luengo 1992), and the scarcity of critical literature aiming at debunking the myths surrounding their differential character (Rovalo Cilleros 1994; Rubio Pérez 2003).

\section{Maragatería Inc.: genetics, regionalism and commodification (1975-2014)}

The end of the Franco dictatorship entailed the dismantling of the official folkloric apparatus that had played a key role in the construction of the ethnic image of the Maragatos. The re-emergence of Maragato identity only took place during the 1990s. This process has taken on multiple dimensions in the context of a neo-liberal world and prevailing commodification. We can divide processes of identity re-emergence into three: the racialization of ethnicity, its connection with regionalist political agendas, and its commodification. These processes reflect the transition from modern metanarratives of national identity to a super-modern era dominated by market logics and the individualization of identity. Here, the cultural representations of Maragato difference and the mysteries surrounding their origin enter a new global framework of relationships. Indeed, as Herzfeld $(2009,121)$ argues, '"tradition", now available worldwide, often depends for its legitimacy on the obscurity of its origins'. 
The scientific racialization of Maragato identity presents a great deal of continuity with previous ideas of history-culture and biology. While different authors keep attempting to decipher the origins of the Maragatos and study their differential traits from linguistic or anthropological perspectives (Ballester 2002), others focus on the investigation of fingertips and prints, blood and genetics (Bernis 1990). A well-endowed research supported by various Spanish research and health agencies studied Maragato mitochondrial DNA. The study sees Maragatos as 'one of the most interesting human cultural isolates in the Iberian Peninsula', allegedly confirming that they are 'a genetically isolated human group' (Larruga et al. 2001, 708). It affirms that their 'cultural peculiarities with attributed resemblances to North African Berbers or to Near East Semitic cultures have differentiated them from their surrounding neighbours ever since' (Larruga et al. 2001, 708). Examined from a wide chronological perspective, it is possible to locate the roots of this affirmation on a longlasting lineage of thought starting with the Inquisition, which associated all suspects of heresy with Moors and Jews. In other words, current genetic research about the Maragatos designs its research questions and hypotheses based on eighteenth-century religious prejudice and essentialized notions of cultural difference.

Although their research uses the apparently neutral term 'population' to refer to the Maragatos, the concept can actually be equated with ethnicity or race as it is predicated through an attachment to a region and discussed in terms of origins (Fujimura and Rajagopalan 2011, 10). Similar to physical anthropology investigations a century before, the underlying rationale for the selection of 'populations' derives from the perception of the Maragatos as socially and culturally different or isolated, which renders them interesting as sources for the investigation of human genetic variation. In doing so, the study 'assumes a correspondence between genetic and cultural difference from the start' (Nash 2013, 195), instead of employing a different sampling strategy based on a neutral geographical grid (Reardon 2009, 77). Populations are neither natural nor linguistic but rather enacted through laboratory and knowledge practices. Therefore, the categorization of human groups as 'populations' should be understood as a political process related to power and socio-economic relations ( $M^{\prime}$ charek 2005). Furthermore, we must bear in mind again the fact that the majority of the Maragato social group emigrated from the area in the early twentieth century, which evinces how these investigations not only presuppose, but also construct a spatial-temporal continuum between genetics, soil and ethnic difference.

The racialization of Maragatos goes hand in hand with regionalist and pseudoscientific works highlighting Maragato cultural difference. Pseudoscientific investigations enjoy a broad public reception that feeds into the popular imagination of the Maragato myth and the obscurity of its origins (González González 2011). Pseudoscientists build on the scarcity of evidence 
about the Maragatos to produce presentist and essentialist discourses about origins, drawing on data gathered through methodologies such as dowsing, archaeoastronomy, or simply through the free interpretation of scientific data in connection with other narratives, especially those of a regionalist bent.

Indeed, the federalization of Spain in 1978 reawakened regionalist claims predicated upon differential cultural traditions. Maragatería is located in the province of León, where a regionalist movement emerged as a banner to be wielded against the Castilian dominance in the new Autonomous Community of Castilla y León. In the attempt to construct a different identity lineage from Castile, the Leonesist movement has developed a discourse based on the establishment of a historical continuity between local pre-Roman Aboriginals, the Astures, and the present region of León. This narrative, assumed and spread by different pseudoscientists with great success, is hardly news: the appropriation of the pre-Roman past is a common strategy employed by various regionalisms in north-west Spain (Marín Suárez, González Álvarez, and Alonso González 2013). Broadly, the implicit discourse holds that preRoman communities and their identities somewhat endured the Roman conquest and acculturation process. Their identities remained in some sort of 'dormant' state throughout history. Allegedly, the pre-industrial communities that still inhabit León, the 'peasants', are the heirs of this tradition. Consequently, those ethnic groups that supposedly have better preserved their traditions and are rooted in the land - like the Maragatos - are perceived as the 'authentic ancestors', that is, more purely Leonese. Paradoxically, the regionalist ideology is assuming the reification of the relationship between territory and culture promoted by Franco's folkloric regionalism, but now with separatist rather than centralist aims.

These discourses, resulting in a recoding and dissolution of the Maragato ethnic construct into a broader discourse of 'Leonese identity', are fed by culture-history ethnographical, historical and anthropological accounts. Indeed, the otherness of Maragatos and some of their traditions, such as snow-ploughing, have been repeatedly linked with pre-Roman Aboriginals (Caro Baroja 1973; Ballester 2002). Similarly, local communal forms of property were historically equated with the 'primitive communism' supposedly held by the Aboriginals (Flórez de Quiñones y Tomé 1924; Jovellanos [1782] 1981). In the attempt to provide ammunition to regionalism, the whole discourse aims at the creation of an unspecified and vague 'we' that goes from the primitive indigenous pre-Roman to the contemporary rural 'peasant', which embodies Leonese identity as opposed to the Castilian other.

The most significant process of identity re-emergence is the commodification of Maragato ethnicity, understood as the 'dialectic that connects the incorporation of identity to the commoditisation of difference' (Comaroff and Comaroff 2009). Today, 'the very constituents of people's embodied identities, their "race" and respective histories that once ensured their persecution 
and subordinate status, could now be transformed into capital' (Meskell 2012, 2). This phenomenon unfolds, first, through the establishment of a neo-liberal governmentality framework that promotes the creation of museums and the tourism promotion of Maragato identity for the sake of favouring ethno-preneurialism. Second, it is connected with the arrival to Maragatería of highly individualized urban second-home buyers.

The first process mostly results from the action of rural development projects promoting the creation of a new 'territorial identity' to attract tourism. In different ways, Maragato identity has been 'incorporated' into tourism discourses and products. The Muleteering Museum in Santiago Millas conveys an essentialist view of the Maragatos and their culture, promoting the performance of Maragato folklore as museum spectacle. The fact that Maragato folklore is still alive and can be experienced in 'real life' reveals the attempt to shape ethnic identities for tourist consumption as metacultural 'traditional' products (Kirshenblatt-Gimblett 2004). Similarly, Maragato villages are being restored and associated with invented traditions, such as the now famous 'Maragato stew', which attracts hundreds of tourists every weekend. Moreover, rural development projects support the creation of 'Maragato-style' hotels and restaurants, profiting from the uniqueness provided by the Maragato difference. This postmodern style recreates an ideal of authenticity inspired by traditional Maragato monumental architecture, characterized by wide stone walls, red tile roofs, and large central patios with stone mosaics (Alonso González 2014).

The reconstruction of Maragato architecture also serves for the reproduction of power relations between social groups. Usually, second-home buyers from urban centres restore large abandoned Maragato monumental houses, or build them from scratch imitating Maragato styles. Urban newcomers often present highly individualized identities and use the house as a symbolic repository to express social distinction. Their houses display on their facades pre-industrial tools as artworks. These tools played a functional role in agricultural work and local neighbours associate them with a past of hardship and poverty. This generates a symbolic hierarchy of difference whereby the past is consumed in the present as metaculture, while at the same time is ranked as 'previous' and 'inferior' to the present in a linear scale of progress. This super-modern process supersedes the characteristics of modernization, because it exacerbates the tendency to create cultural representations of others while not recognizing their actual alterity. The consumption of Maragato ethnicity has become a crucial vector to channel the process of individualization because it provides symbols 'that can represent the manifold differences that exist today, and which can facilitate the visualisation of that effort of differentiation, that particularisation that defines identity' (Hernando Gonzalo 2002, 191). 


\section{Conclusions}

This paper has explored the processes that have produced the specific Maragato ethnicity or, rather, the contexts in which their difference has been constructed from specific knowledge-power articulations. Those changing articulations of scientific epistemologies, nationalism and politics fix thresholds of uniformity and otherness that make it possible to classify disparate subjects in a continuum from 'inappropriate or inacceptable' to 'folklorized or marketable' subordinates on the basis of ideas about a shared substance, either through notions of nature, blood and race, or cultural discourses about soil, history and culture. Indeed, the machinery that surrounds the production of ethnicity usually involves a traffic between ideas of culture as ethnicity, and nature as race. Thus, accounting for the ontologically different other involves the epistemologies of the social and natural sciences.

The traffic between notions of culture, ethnicity and identity shows that the distinction between civic and ethnic nationalism in Spain is analytically useful but ontologically bogus. This framework should be superseded by a detailed account of the changing constructions of notions of territory, race, culture and ethnicity as grounds for national identity. This paper has attempted to deconstruct the dichotomy between civic identities as based on rational decisions and cultural and ethnic identities as inherited and emotional. Scientists often ground their rational discourses on cultural and ethnic prejudices, while nation states produce images of certain social groups as different, and attempt to identify them as such on a scientific basis. This suggests that there is no orchestrated plan in the creation of national polities, but rather an ongoing interplay between notions of citizenship, ethnicity and culture that should be analytically engaged as a dynamic process.

The broad chronological scope of this study allows an understanding of the constant historical interplay between notions of the Spanish 'we' and the various constructions of ethnic, racial or commodified others. It reveals how, for instance, contemporary genetic research with significant financial resources can design its research agenda based on essentialist discourses about certain others developed centuries ago. Similarly, it shows how the cultural representations of ethnic groups can endure more than their real counterparts, as occurred with the Maragatos.

This evinces that the investigation of cultural homogenization requires focusing on two levels of analysis to account for the twofold modernist process whereby cultural alterity is first materially subsumed and homogenized, and then symbolically abstracted as a cultural representation of difference promoted by science, nation states or commodification processes. Without overstating the role of Maragatos in Spanish nation building, this paper has suggested that the reified cultural representations of ethnic groups considered as cursed internal others have served as a backdrop against which to construct 
hegemonic discourses of a majority Spanish identity. More research is needed to understand the relation between the representations of other 'cursed' minorities, and nation building, power regimes and changing scientific paradigms in Spain, and it is the hope of this paper to spark debate on the topic.

\section{Disclosure statement}

No potential conflict of interest was reported by the authors.

\section{ORCID}

\section{Pablo Alonso-González (1) http://orcid.org/0000-0002-5964-0489}

\section{References}

II Día Provincial de las Comarcas Leonesas. 1962. Tierras de León 3 (2): 91-106.

Alonso, Ana María. 1994. "The Politics of Space, Time and Substance: State Formation, Nationalism and Ethnicity." Annual Review of Anthropology 23 (3): 379-405.

Alonso Garrote, Santiago. 1909. El dialecto vulgar leonés: hablado en Maragateria y Tierra de Astorga. Astorga: Imprenta López.

Alonso González, Pablo. 2014. “The Heritage Machine: The Neoliberal Order and the Individualisation of Identity in Maragatería (Spain)." Identities 22 (4): 397-415. doi:10.1080/1070289X.2014.977291.

Alonso González, Pablo, and Juan Miguel Álvarez Domínguez. 2013. “El 'Centro Val de San Lorenzo' en Buenos Aires: emigración e identidad en la Maragatería (León, España)." Studia Histórica: Historia Contemporánea 31: 219-243.

Alonso González, Pablo, and Alfredo Macías Vázquez. 2014. "Bombardeando patrimonio en el Campo Militar de Tiro del Teleno (León): de la sublimación de la naturaleza a la construcción social del patrimonio cultural." Arbor 190 (766): 1-10.

Alonso Luengo, Luis. 1992. Los Maragatos: Su origen, su estirpe, sus modos. León: Lancia. Appadurai, Arjun. 2006. Fear of Small Numbers: An Essay on the Geography of Anger. Durham: Duke University Press.

Aragón y Escacena, Federico. 1902. Breve estudio antropológico acerca del pueblo maragato. Madrid: Fortanet.

Archilés, Ferrán, and Marta García Carrión. 2013. "En la sombra del Estado. Esfera pública nacional y homogeneización cultural en la España de la Restauración." Historia Contemporánea 45: 483-518.

Ballester, Xaverio. 2002. "Sobre el origen anindoeuropeo de los ástures y Maragatos." Palaeohispánica: Revista sobre lenguas y culturas de la Hispania antigua 2: 71-87.

Bel i Queralt, Germa. 2012. Infrastructure and the Political Economy of Nation Building in Spain, 1720-2010. Portland, OR: Sussex Academic Press.

Bernis, Cristina. 1975. Estudio biodemográfico de la población maragata. Madrid: Publicaciones de la Facultad de Ciencias.

Bernis, Cristina. 1990. "Behavioural Changes Concerning the Parity Limitation Problem in Rural Spain: La Maragateria." International Journal of Anthropology 5 (3): 215-221.

Brandes, Stanley. 2011. "El nacimiento de la Antropología Social en España." In Lugares, tiempos, memorias: la antropología ibérica en el siglo XXI, edited by Luis Díaz Viana, Óscar Fernández Álvarez, and Pedro Tomé Martín, 27-50. León: Universidad de León. 
Callahan, William James. 1972. Honor, Commerce and Industry in Eighteenth-century Spain. Boston: Baker Library.

Capel Sáez, Horacio. 2009. “La antropología española y el magisterio de Claudio Esteva Fabregat. Estrategias institucionales y desarrollo intelectual en las disciplinas científicas." Scripta Nova 13 (287). http://www.ub.edu/geocrit/sn/sn-287.htm.

Caro Baroja, Julio. 1973. Los pueblos del norte de la península ibérica: Análisis históricocultural. San Sebastian: Txertoa.

Caro Baroja, Julio. 2003. Los pueblos de España, 2. Madrid: Alianza.

Caro Dobón, Luis. 1986. Antropometría de la población leonesa. León: Institución Fray Bernardino de Sahagún.

Carro y Carro, Julio. 1955. Maragatería, el Bierzo, Galicia, Siria y Palestina, en antigua y desconocida ligazón histórica. Madrid: Maribel Arte Gráficas.

Casado, Concha, and Antonio Carreira Vérez. 1985. Viajeros por León: siglos XII-XIX. León: Santiago García.

Ciria y Vincent, Joaquín. 1909. "Excursiones en la provincia de León: el país de los Maragatos; las montañas del Teleno; las antiguas minas romanas." Boletín de la Real Sociedad Geográfica 51: 41-80.

Comaroff, John L., and Jean Comaroff. 2009. Ethnicity, Inc. Chicago: University of Chicago Press.

Conversi, Daniele. 2008. "We are All Equals!' Militarism, Homogenization and 'Egalitarianism'in Nationalist State-building (1789-1945)." Ethnic and Racial Studies 31 (7): 1286-1314.

Conversi, Daniele. 2013. "Nación, estado y cultura: por una historia política y social de la homogeneización cultural." Historia Contemporánea 45: 437-481.

Dozy, Reinhart. 1859. Investigaciones acerca de la historia y de la literatura de Espana durante la edad media. España: Biblioteca Cientifico-Literaria.

Escudero Barbero, Roberto, and Javier García-Prieto. 1984. Viajes y viajeros por tierras de León (1494-1966). Oviedo: Saturio.

Flórez de Quiñones y Tomé, Vicente. 1924. Contribución al estudio del régimen local y de la Economía Popular de España. Los pueblos agregados a un término municipal en la Historia, en la Legislación vigente y en el Derecho Consuetudinario Leonés. León: Imprenta Católica.

Ford, Richard. 1906. Gatherings from Spain. London, New York: Dent; Dutton.

Freeman, Susan. 2011. "Recursos y temática para el trabajo de campo en España, 19621990." In Lugares, tiempos, memorias: la antropología ibérica en el siglo XXI, edited by Luis Díaz Viana, Óscar Fernández Álvarez and Pedro Tomé Martín, 51-64. León: Universidad de León.

Fujimura, Joan H., and Ramya Rajagopalan. 2011. "Different Differences: The Use of 'Genetic Ancestry' versus Race in Biomedical Human Genetic Research." Social Studies of Science 41 (1): 5-30.

García Escudero, Ricardo. 1953. Por tierras maragatas. Astorga: Cornejo.

García-Arenal, Mercedes and Fernando Rodríguez Mediano. 2013. The Orient in Spain: Converted Muslims, the Forged Lead Books of Granada, and the Rise of Orientalism. Boston: Brill.

González González, Miguel Ángel. 2011. Teleno, señor del laberinto, del rayo y de la muerte. León: Lobo Sapiens.

Goode, Joshua. 2009. Impurity of Blood: Defining Race in Spain, 1870-1930. Baton Rouge: Louisiana State University Press.

Grosfoguel, Ramon and Eric Mielants. 2006. “The Long-Durée Entanglement between Islamophobia and Racism in the Modern/Colonial Capitalist/Patriarchal Worldsystem: An Introduction." Human Architecture 5 (1): 1-12. 
Gutiérrez González, José Avelino. 1983. "Notas para una antropología cultural de la maragatería." Lancia: revista de prehistoria, arqueología e historia antigua del noroeste peninsular 1: 283-291.

Hernando Gonzalo, Almudena. 2002. Arqueología de la Identidad. Madrid: Akal.

Herzfeld, Michael. 2009. "Rhythm, Tempo, and Historical Time: Experiencing Temporality in the Neoliberal Age." Public Archaeology 8 (2-3): 2-3.

Hors, Pilar. 1951. "Seroantropología de leoneses y Maragatos." Hematología y Hemoterapia 1: 99-100.

Jovellanos, Gaspar Melchor de. 1858. Obras publicadas é inéditas de D. Gaspar Melchor de Jovellanos, Tomo 50. Madrid: Rivadeneyra.

Jovellanos, Gaspar Melchor de. [1782] 1981. Cartas del Viaje de Asturias, 3. Asturias: Ayalga. Kirshenblatt-Gimblett, Barbara. 2004. "From Ethnology to Heritage: The Role of the Museum." Paper presented at the SIEF Keynote, Marseille.

Lafuente, Modesto, and Juan Sisinio Pérez Garzón. [1850] 2002. Historia general de España desde los tiempos más remotos hasta nuestros días: discurso preliminar. Pamplona: Urgoiti.

Larruga, José María, Fernando Díez, Francisco Pinto, Carlos Flores, and Ana María González. 2001. "Mitochondrial DNA Characterisation of European Isolates: The Maragatos from Spain." European Journal of Human Genetics 9 (9): 708-716.

Lisón Tolosana, Carmelo. 1980. Invitación a la antropología cultural de España. Madrid: Akal.

Luengo Martínez, José María. 1990. Estudios arqueológicos: homenaje del Exmo. Ayuntamiento de Astorga. Astorga: Ayuntamiento de Astorga.

Mandelbaum, Moran. 2013. "The Gellnerian Modality Revisited: Towards a 'Genealogy'of Cultural Homogenization and Nation-state Congruency." Ethnic and racial studies 37 (11): 1-20.

Martín Galindo, José Luis. 1956. "Arrieros leoneses: los arrieros Maragatos." Archivos Leoneses: revista de estudios y documentación de los Reinos Hispano-Occidentales 19: 153-179.

Marín Suárez, Carlos, David González Álvarez, and Pablo Alonso González. 2013. “Building nations in the XXI century. Celtism, Nationalism and Archaeology in northern Spain: the case of Asturias and León." Cambridge Archaeological Review 27 (2): 11-32.

Martínez Veiga, Ubaldo. 1981. "Etnicidad y nacionalismo." Documentación Social: Revista de Estudios Sociales y Sociología Aplicada 45: 11-28.

M'charek, Amade. 2005. "The mitochondrial Eve of Modern Genetics: Of Peoples and Genomes, or the Routinization of Race." Science as Culture 14 (2): 161-183.

Melis Maynar, Ana. 1976. "Aspectos antropológicos-sociales en Maragatería." PhD, Universidad Complutense de Madrid.

Méndez Diego, Irene. 1982. Estudio dermopapilar de la población maragata. León: Universidad de León.

Meskell, Lynn. 2012. The Nature of Heritage: The New South Africa. Malden: WileyBlackwell.

Michel, Francisque. 1847. Histoire des races maudites de la France et de l'Espagne. Paris: Franck.

Miner Otamendi, José Manuel. 1978. Los pueblos malditos: agotes, pasiegos, vaqueiros de alzada, Maragatos, chuetas. Madrid: Espasa Calpe.

Morán Bardón, César. 1925. Por tierras de León. León: Diputación de León.

Moreno, Luis. 2001. The Federalization of Spain. London, Portland: F. Cass.

Muro, Diego, and Alejandro Quiroga. 2005. "Spanish Nationalism. Ethnic or Civic?" Ethnicities 5 (1): 9-29. 
Nash, Catherine. 2013. "Genome Geographies: Mapping National Ancestry and Diversity in Human Population Genetics." Transactions of the Institute of British Geographers 38 (2): 193-206.

Oliveira Martins, Joaquím Pedro. 1894. Historia de la civilización ibérica. Madrid: Fortanet.

Ortiz García, Carmen. 1996. “La antropología española en el primer tercio del siglo XX: Líneas de continuidad y rupturas." In De la construcción de la historia a la práctica de la antropología en España, edited by Encarnación Aguilar Criado, 121-130. Zaragoza: Instituto Aragonés de Antropología.

Ortiz García, Carmen. 1999. "The Uses of Folklore by the Franco Regime." Journal of American Folklore 112: 479-496.

Ortiz García, Carmen. 2003. "Antropología en España (1970-2000)." In Anuario: Centro de Estudios Superiores de México y Centroamérica, 13-24. Chiapas: Universidad de Chiapas.

Ortiz-Echagüe, José. 1943. España mística. San Sebastián: Editora internacional.

Peña Sanz, Miguel. 1962. "Instituciones Jurídicas y Sociales de Maragatería en la Edad Moderna." PhD, Universidad Complutense de Madrid.

Porqueres i Gené, Enric. 2002. "Nación, Parentesco y Religión: el Nacionalismo Vasco Entre la Sangre y la Tierra de la Patria." In Identidades, Relaciones y Contextos, edited by J. Bestard Camps, 47-70. Barcelona: Barcelona University.

Prat Carós, Joan. 1992. Antropología y etnología. Madrid: Complutense.

Quintana Prieto, Augusto. 1978. Los Maragatos y su tierra: Breves consideraciones. Astorga: Cornejo.

Rae, Heather. 2002. State Identities and the Homogenisation of Peoples. Cambridge: Cambridge University Press.

Reardon, Jenny. 2009. Race to the Finish: Identity and Governance in an Age of Genomics. Princeton: Princeton University Press.

Rovalo Cilleros, Emilio. 1994. Los Maragatos: La caída de un mito. Madrid: Gama.

Rubio Pérez, Laureano. 2003. Los Maragatos. Origen, mitos y realidades. Zamora: Monte Casino.

Sáez de Melgar, Faustina. 1881. Las mujeres españolas, americanas y lusitanas pintadas por sí mismas. Barcelona: Juan Pons.

Sarmiento, Fray Martín. 1787. "Discurso crítico sobre el origen de los Maragatos." In Semanario erudito, 175-214. Madrid: Blas Román.

Viejo-Rose, Dacia. 2011. Reconstructing Spain: Cultural Heritage and Memory after Civil War. Brighton: Sussex Academic Press.

Wade, Peter. 2007. "Perspectives from Kinship and Genetics." In Race, Ethnicity and Nation: Perspectives from Kinship and Genetics, edited by Peter Wade, 1-32. New York: Berghahn Books.

Weber, Eugen. 1976. Peasants into Frenchmen: The modernization of Rural France, 18701914. Stanford: Stanford University Press. 